\title{
Portion Size Estimation of Indian Flats Breads in Terms of Weight
}

\author{
K. Mahajani ${ }^{1 *}$, S. Jain ${ }^{2}$ and B.L. Dhaka ${ }^{3}$ \\ ${ }^{1}$ Subject Matter Specialist, KVK Bundi, AU Kota, India \\ ${ }^{2} C C \& A S, M P U A T$, Udaipur, India \\ ${ }^{3}$ Agriculture Extension, KVK Bundi, AU Kota, India \\ *Corresponding author
}

\section{A B S T R A C T}

\section{Keywords}

Chapati, Bhatura, parantha, Portion size, SSPS

Article Info

Accepted:

07 January 2019

Available Online:

10 February 2019
The present study was conducted to assess the portion size of Indian Flats breads in terms of weight. A total of hundred home makers were purposively selected for study. Standard unit technique and weighing record method were applied. Results revealed that 52 percent women belonging from age of (20-30 years). 41 percent were Hindu followed by Muslim respondents $(39 \%)$, respondents were from the nuclear family $(88 \%)$ than joint family (12\%). Portion size for raddish parantha $(100 \mathrm{~g})$, maize chapatti $(81 \mathrm{~g})$, bhatura (plain, fried) $(100 \mathrm{~g})$, bhatura (colocasia stuffed and fried) (181g) was equal to the SSPS. For bhatura $(100 \mathrm{~g})$ and chapatti $(73.8 \mathrm{~g})$ nearly 70 percent of women reported portion size equal to SSPS. It can be seen that more than 70 percent of the women considered the portion size of ragi roti, maize chapati (colocasia stuffed) and plain roasted bhatura was $25 \%$ less of SSPS. In case of cauliflower parantha a high majority of women (80\%) reported portion size $50 \%$ less of SSPS. In the finding in present study showed that larger portion size was obsereved for plain paratha, potato paratha radish, cauliflower paratha, bajra flour roti, chppati, missi chappati, maize methi chappati, batura were found.

\section{Introduction}

Cereals and millets are grown in over 73 percent of the total world harvested area and contribute over 60percent of the world food production providing dietary fibre, proteins, energy, minerals, and vitamins required for human health Das et al., (2012). Cereals are the part and parcel of Indian diet and provide energy and several other nutrients at a very low cost. These are the cheapest and widely available source of nutrients, particularly in developing countries like India. Wheat forms the basic ingredient for various bakery and traditional products. Wheat-based flat breads are one of the traditional products prepared in different parts of the world.

Different regions of the world have inherited different preparation methods since time immemorial, which has led to the existence of traditional flat breads' (Parimala and Sudha 2013). Serving size is an important determinant of how much people eat, independent of hunger levels (Capaldi, 1996), and larger serving sizes are associated with higher energy intakes (Matthiessen et al., 2003). Estimating how much is 
appropriate to consume can be difficult. Research suggests that appropriate portion sizes of some items can be particularly hard to judge, such as highly palatable foods with low satiating effects (Prentice and Jebb, 2003; Yeomans et al., 2004), energy-dense foods (Anderson et al., 2008; Carels et al., 2007; Japur and Diez-Garcia, 2010). Finally, evidence suggests that the perception of an item as being a beverage, a meal or a snack may trigger certain cognitive processes that affect how much we chose to consume (Capaldi et al., 2006; Shimizu et al., 2010). Portion size estimation has been recognized as one of the main sources of inaccuracy in nutritional assessment.

Accurate dietary intake information is essential to properly evaluate an individual's diet relative to recommendations, to relate dietary intakes to health and disease and lastly evaluate the effectiveness of interventions. Portion size can be defined as the amount of food individual choose to eat during a single eating occasion (whether it is a meal out, at home, or even the amount offered within a prepackaged snack), while a serving is a standardized measurement of food or drink.

Large portion sizes contribute to weight gain in societies. Portion-size interventions, aids and education can be effective in helping prevent weight gain, but consumers are unsure what appropriate portions are and express confusion about existing guidelines. A lack of clarity about suggested serving size recommendations is a major barrier to food portion-size control. Therefore, standardized measurement units and unambiguous terminologies are required. So the present study was conducted with following objectives to evaluate the portion size of flat Indian breads. To find out the differences between consumed portion sizes and the Suggested standard portion size.

\section{Materials and Methods}

The study was undertaken municipal limit of Udaipur city, Rajasthan. A list of flat Indian bread was prepared from the available literature, scientific research paper, popular literature (text books, newspapers, publication). Internet was also thoroughly surfed for collection of cooked food products. Hundred homemakers were purposively selected residing in Udaipur city considering their interest and have the knowledge of nutrition. For the evaluation of the portion size (weight) from homemakers, a tool was developed to gather information. This included background information of subjects, details of Indian flat breads. This tool was introduced to the home makers and asked to provide information about portion size of products used by them in family for an adult person. It was decided to use five standard units per food to evaluate portion size. First size was suggested standard size which was obtained from the available literature (Nutriguide, 2002 and Haraldsdottir, 1993). Second was less than 25 percent of the standard size third was less than 50 percent of standard size fourth size was more than 25 percent of standard size and fifth was more than 50 percent of standard size. Weighed Food Records (WFR), also called weighed food diaries or simply weighed records, are considered the "gold standard" of quantitative dietary assessment methods (Carlsen et al., 2010). Respondents were asked according to their feasibility to evaluation the portion size of cooked recipes in terms of weight $(\mathrm{g})$.

\section{Results and Discussion}

\section{Socio economic profile of respondents}

The information gathered from individual respondents on their personal particulars including age, educational level, and religion, family type and food habits have been 
suitably classified to depict a clear picture of the respondents in the study.

The socio economic characteristics of respondents were analysed and presented in Table 1. Data regarding age highlighted that 52 percent women belonging from age of (2030 years). Group 41-50 years found 35 percent women. Only 13percent women were age of 31-40 years. Education level at the time of study indicated that majority $(48 \%)$ of the respondents were undergraduate. While 40 percent respondents were post graduate. Further, very few (12\%) were qualified class $12^{\text {th }}$ only. Data of religion 41 percent were Hindu. Followed by Muslim respondents (39\%) and only 11 and 10 percent respondents were belongs to the Sikh and Christan religion respectively. Regarding the family, it was observed that out of total 100 respondents majority of respondents were from the nuclear family $(88 \%)$ than joint family (12\%). further data revealed that maximum respondents were vegetarian (41\%). Remaining were non vegetarian and eggitarian (40\% and 19\% respectively).

A paratha is a flatbread that originated in the Indian subcontinent. The paratha is an important part of a traditional breakfast from the Indian subcontinent. It can be eaten as a breakfast dish or as a tea-time (tiffin) snack.

The data have been organized and analyzed taking into account the objectives of the study presented in Table 2. The results depicts that 55 percent women reported portion size $25 \%$ more of SSPS for Plain Parantha and Patato parantha. While Spinach paratha was evaluated by 77.78 percent respondents in $50 \%$ more of SSPS. It can seen that 80 percent women supported Portion size of radish parantha equal to SSPS and less than 50 percent of SSPS for cauliflower parantha respectively.

Data highlighted after perusal of Table 3 that different types of chapatti's consumption was also differ. That's why present study showed that out of 60 women 40 women supported portion size $25 \%$ more of SSPS for bajra chapatti. More than 70 percent supported portion size equal to SSPS for maize chapatti and wheat chapatti. While Ragi Chapati (70.59\%) and Maize Chapati (Colocasia Stuffed) $(73.33 \%)$ were favored in $25 \%$ less of SSPS category.

The findings of the present study presented in Table 4 revealed that more than 50 women consuming bhatura except Bhatura (Colocasia Stuffed and fried). Further, the portion size was equal to SSPS for plain bhatura (66.67\%), Bhatura (Plain, Fried) (80\%), Bhatura (Colocasia Stuffed and fried)(80\%). It was recorded that no one found in $50 \%$ more and less of SSPS.

The portion sizes for food categories under the bread and cereal group were generally larger than the ADG standard serves (e.g. 40 $\mathrm{g}$ of bread and $30 \mathrm{~g}$ of breakfast cereals) supported by Zheng et al., (2016).

Table 5 depicts that a highly significant difference was found for plain parantha, spinach parantha, raddish parantha, cauliflower parantha whereas no significant was observed for potato parantha. A larger portion size compare to SSPS was recorded except cauliflower parantha.

In general, declared serving sizes of products within grain (cereal) wraps and flatbreads were substantially greater than the ADG standard serves reported by Yang et al., (2018). 
Table.1 Percentage distribution of respondents in view of background information

\begin{tabular}{|r|l|l|l|}
\hline S.No. & Particulars & Number(n=100) & Percentage \\
\hline 1. & Age (years) & & \\
\hline & $20-30$ & $\mathbf{5 2}$ & $\mathbf{5 2 \%}$ \\
\hline & $31-40$ & $\mathbf{1 3}$ & $\mathbf{1 3 \%}$ \\
\hline 2. & Ed-50 & $\mathbf{3 5}$ & $\mathbf{3 5 \%}$ \\
\hline & Below 12th & & \\
\hline & Under graduation & $\mathbf{4 8}$ & $\mathbf{1 2 \%}$ \\
\hline & Post graduation & $\mathbf{4 0}$ & $\mathbf{4 8 \%}$ \\
\hline 3. & Religion & & $\mathbf{4 0 \%}$ \\
\hline & Hindu & $\mathbf{4 1}$ & \\
\hline & Muslim & $\mathbf{3 9}$ & $\mathbf{4 1 \%}$ \\
\hline & Sikh & $\mathbf{1 1}$ & $\mathbf{3 9 \%}$ \\
\hline & Cristan & $\mathbf{1 0}$ & $\mathbf{1 1 \%}$ \\
\hline 4. & Family type & & $\mathbf{1 0 \%}$ \\
\hline & Nuclear & $\mathbf{8 8}$ & \\
\hline & Joint family & $\mathbf{1 2}$ & $\mathbf{8 8 \%}$ \\
\hline 4. & Food habits & & $\mathbf{1 2 \%}$ \\
\hline & Vegetarian & $\mathbf{4 1}$ & $\mathbf{4 1 \%}$ \\
\hline & Non vegetarian & $\mathbf{4 0}$ & $\mathbf{1 9 \%}$ \\
\hline & Eggitarian & $\mathbf{1 9}$ & \\
\hline
\end{tabular}

Table.2 Frequency distribution of respondents for portion size of different type of parantha

\begin{tabular}{|c|c|c|c|c|c|c|c|c|}
\hline S.No. & $\begin{array}{l}\text { Name of } \\
\text { Parantha's }\end{array}$ & $\mathbf{N}$ & $\begin{array}{c}\text { SSPS } \\
\text { (g) }\end{array}$ & $\begin{array}{l}50 \% \\
\text { less } \\
\text { of } \\
\text { SSPS }\end{array}$ & $\begin{array}{l}25 \% \\
\text { less of } \\
\text { SSPS }\end{array}$ & $\begin{array}{l}\text { Equal } \\
\text { to SSPS }\end{array}$ & $\begin{array}{l}25 \% \\
\text { more of } \\
\text { SSPS }\end{array}$ & $\begin{array}{l}50 \% \\
\text { more of } \\
\text { SSPS }\end{array}$ \\
\hline 1. & $\begin{array}{l}\text { Plain } \\
\text { Parantha }\end{array}$ & 100 & 56.5 & 0 & 0 & $\begin{array}{l}45 \\
(45)\end{array}$ & $\begin{array}{l}55 \\
(55)\end{array}$ & 0 \\
\hline 2. & $\begin{array}{l}\text { Potato } \\
\text { Parantha }\end{array}$ & 100 & 68 & 0 & 0 & $\begin{array}{l}10 \\
(10)\end{array}$ & $\begin{array}{l}55 \\
(55)\end{array}$ & $\begin{array}{l}35 \\
(35)\end{array}$ \\
\hline 3. & $\begin{array}{l}\text { Spinach } \\
\text { Parantha }\end{array}$ & 90 & 60 & 0 & 0 & 0 & $\begin{array}{l}20 \\
(22.22)\end{array}$ & $\begin{array}{l}70 \\
(77.78)\end{array}$ \\
\hline 4. & $\begin{array}{l}\text { Raddish } \\
\text { Parantha }\end{array}$ & 50 & 100 & 0 & 0 & $\begin{array}{l}40 \\
(80)\end{array}$ & $\begin{array}{l}10 \\
(20)\end{array}$ & 0 \\
\hline 5. & $\begin{array}{l}\text { Cauliflower } \\
\text { Parantha }\end{array}$ & 100 & 210 & $\begin{array}{l}80 \\
(80)\end{array}$ & $\begin{array}{l}10 \\
(10)\end{array}$ & $\begin{array}{l}10 \\
(10)\end{array}$ & 0 & 0 \\
\hline
\end{tabular}

*SSPS= Suggested standard portion size

Values in parenthesis represent percentage of respondents 
Table.3 Frequency distribution of respondents for portion size of different type of Chapati's

\begin{tabular}{|c|c|c|c|c|c|c|c|c|}
\hline S.No. & $\begin{array}{l}\text { Name of } \\
\text { Chapatti's }\end{array}$ & $\mathbf{N}$ & $\begin{array}{l}\text { SSPS } \\
(\mathrm{g})\end{array}$ & $\begin{array}{c}50 \% \text { less } \\
\text { of SSPS }\end{array}$ & $\begin{array}{l}25 \% \text { less } \\
\text { of SSPS }\end{array}$ & $\begin{array}{l}\text { Equal to } \\
\text { SSPS }\end{array}$ & $\begin{array}{l}25 \% \text { more } \\
\text { of SSPS }\end{array}$ & $\begin{array}{l}50 \% \\
\text { more of } \\
\text { SSPS }\end{array}$ \\
\hline 1. & Bajra Chapati & 60 & 81 & 0 & 0 & $\begin{array}{l}20 \\
(33.33)\end{array}$ & $\begin{array}{l}40 \\
(66.67)\end{array}$ & 0 \\
\hline 2. & Maize Chapati & 80 & 81 & 0 & 0 & $\begin{array}{l}70 \\
(87.5)\end{array}$ & 0 & $\begin{array}{l}10 \\
(12.5)\end{array}$ \\
\hline 3. & Bajra flour Chapati & 80 & 40 & 0 & 0 & $\begin{array}{l}40 \\
(50)\end{array}$ & $\begin{array}{l}40 \\
(50)\end{array}$ & 0 \\
\hline 4. & $\begin{array}{l}\text { Jawar Flour, } \\
\text { Chapati }\end{array}$ & 20 & 90 & 0 & $\begin{array}{l}10 \\
(50)\end{array}$ & $\begin{array}{l}10 \\
(50)\end{array}$ & 0 & 0 \\
\hline 5. & Ragi Chapati & 17 & 100 & 0 & $\begin{array}{l}12 \\
(70.59)\end{array}$ & $\begin{array}{l}5 \\
(29.41)\end{array}$ & 0 & 0 \\
\hline 6. & Wheat Chapati & 100 & 73.8 & 0 & 0 & $\begin{array}{l}70 \\
(70)\end{array}$ & $\begin{array}{l}30 \\
(30)\end{array}$ & 0 \\
\hline 7. & Missi Chapati & 70 & 81 & 0 & 0 & 0 & $\begin{array}{l}50 \\
(71.43)\end{array}$ & $\begin{array}{l}20 \\
(28.57)\end{array}$ \\
\hline 8. & $\begin{array}{l}\text { Maize Methi } \\
\text { Chapati }\end{array}$ & 60 & 100 & 0 & 0 & $\begin{array}{l}30 \\
(50)\end{array}$ & $\begin{array}{l}20 \\
(33.33)\end{array}$ & $\begin{array}{l}10 \\
(16.67)\end{array}$ \\
\hline 9. & $\begin{array}{l}\text { Maize Chapati } \\
\text { (Colocasia Stuffed) }\end{array}$ & 30 & 230 & 0 & $\begin{array}{l}22 \\
(73.33)\end{array}$ & $\begin{array}{l}8 \\
(26.67)\end{array}$ & 0 & 0 \\
\hline
\end{tabular}

*SSPS= Suggested standard portion size

Values in parenthesis represent percentage of respondents

Table.4 Frequency distribution of respondents for portion size of different type of Bhatura's in terms of weight

\begin{tabular}{|c|c|c|c|c|c|c|c|c|}
\hline S.No. & $\begin{array}{l}\text { Name of } \\
\text { Bhatura's }\end{array}$ & $\mathbf{N}$ & $\begin{array}{c}\text { SSPS } \\
\text { (g) }\end{array}$ & $\begin{array}{l}50 \% \\
\text { less } \\
\text { of } \\
\text { SSPS }\end{array}$ & $\begin{array}{l}25 \% \text { less } \\
\text { of SSPS }\end{array}$ & $\begin{array}{l}\text { Equal to } \\
\text { SSPS }\end{array}$ & $\begin{array}{l}25 \% \text { more } \\
\text { of SSPS }\end{array}$ & $\begin{array}{l}50 \% \\
\text { more of } \\
\text { SSPS }\end{array}$ \\
\hline 1. & Plain Bhatura & 60 & 100 & 0 & 0 & $\begin{array}{l}40 \\
(66.67)\end{array}$ & $\begin{array}{l}20 \\
(33.33)\end{array}$ & 0 \\
\hline 2. & $\begin{array}{l}\text { Plain Roasted } \\
\text { Bhatura }\end{array}$ & 60 & 138 & 0 & $\begin{array}{l}45 \\
(75)\end{array}$ & $\begin{array}{l}15 \\
(25)\end{array}$ & 0 & 0 \\
\hline 3. & $\begin{array}{l}\text { Bhatura (Plain, } \\
\text { Fried) }\end{array}$ & 50 & 100 & 0 & $\begin{array}{l}5 \\
(10)\end{array}$ & $\begin{array}{l}40 \\
(80)\end{array}$ & $\begin{array}{l}5 \\
(10)\end{array}$ & 0 \\
\hline 4. & $\begin{array}{l}\text { Bhatura (Dal } \\
\text { Stuffed) }\end{array}$ & 50 & 188 & 0 & $\begin{array}{l}15 \\
(30)\end{array}$ & $\begin{array}{l}20 \\
(40)\end{array}$ & $\begin{array}{l}15 \\
(30)\end{array}$ & 0 \\
\hline 5. & $\begin{array}{l}\text { Bhatura } \\
\text { (Colocasia } \\
\text { Stuffed and } \\
\text { fried) }\end{array}$ & 10 & 181 & 0 & $\begin{array}{l}2 \\
(20)\end{array}$ & $\begin{array}{l}8 \\
(80)\end{array}$ & 0 & 0 \\
\hline
\end{tabular}

*SSPS $=$ Suggested standard portion size

Values in parenthesis represent percentage of respondents 
Table.5 Mean \pm SD and t-values of portion size of cereals and millet based food products for in terms of weight

\begin{tabular}{|c|c|c|c|c|c|c|c|c|}
\hline $\begin{array}{l}\text { S.No } \\
\text {. }\end{array}$ & Name of Parantha's & $\mathbf{N}$ & $\begin{array}{l}\text { SSPS } \\
(\mathrm{g})\end{array}$ & Mean & Difference & SD & SE & t-value \\
\hline 1. & Plain Parantha & 100 & 56.5 & 64.27 & 7.77 & 7.06 & 0.71 & $11.000^{* *}$ \\
\hline 2. & Potato Parantha & 100 & 68 & $\begin{array}{l}190.7 \\
3\end{array}$ & 122.73 & 101.14 & 10.61 & $1.21^{\mathrm{NS}}$ \\
\hline 3. & Spinach Parantha & 90 & 60 & 86.67 & 26.67 & 6.27 & 0.66 & $40.341 * *$ \\
\hline 4. & Raddish Parantha & 50 & 100 & $\begin{array}{l}105.0 \\
0\end{array}$ & 5 & 10.10 & 1.43 & $3.500 * *$ \\
\hline 5. & Cauliflower Parantha & 100 & 210 & $\begin{array}{l}120.7 \\
5\end{array}$ & -89.25 & 33.79 & 3.38 & $26.416^{* *}$ \\
\hline
\end{tabular}

** Significant at $1 \%(\mathrm{P}<0.01)$.

* Significant at $5 \%(\mathrm{P}<0.05)$.

NS: Non Significant

Table.6 Mean \pm SD and t-values of portion size of cereals and millet based food products for in terms of weight

\begin{tabular}{|c|c|c|c|c|c|c|c|c|}
\hline $\begin{array}{l}\text { S.N } \\
\text { o. }\end{array}$ & Name of Chapatti's & $\mathbf{N}$ & $\begin{array}{l}\text { SSPS } \\
(\mathrm{g})\end{array}$ & Mean & Difference & SD & SE & t-value \\
\hline 1. & Bajra chapati & 60 & 81 & 94.50 & 13.5 & 9.63 & 1.24 & $10.863 * *$ \\
\hline 2. & Maize chapati & 80 & 81 & 86.06 & 5.06 & 13.48 & 1.51 & $3.359 * *$ \\
\hline 3. & Bajra flour chapati & 80 & 40 & 45.00 & 5 & 5.03 & 0.56 & $8.888 * *$ \\
\hline 4. & Jawar Flour, chapati & 20 & 90 & 78.75 & -11.25 & 11.54 & 2.58 & $4.359 * *$ \\
\hline 5. & Ragi chapati & 17 & 100 & 82.35 & -17.65 & 11.74 & 2.85 & $6.197 * *$ \\
\hline 6. & Wheat Chapati & 100 & 73.8 & 79.34 & 5.54 & 8.50 & 0.85 & $6.514 * *$ \\
\hline 7. & Missi chapati & 70 & 81 & 107.04 & 26.04 & 9.21 & 1.10 & $23.641 * *$ \\
\hline 8. & Maize methi chapati & 60 & 100 & 116.67 & 16.67 & 18.79 & 2.43 & $6.870 * *$ \\
\hline 9. & $\begin{array}{l}\text { Maize Chapati (Colocasia } \\
\text { Stuffed) }\end{array}$ & 30 & 230 & 187.83 & -42.17 & 25.86 & 4.72 & $8.930 * *$ \\
\hline \multicolumn{9}{|c|}{$\begin{array}{l}\text { ** Significant at } 1 \%(\mathbf{P}<0.01) \text {. } \\
\text { * Significant at } 5 \%(\mathbf{P}<0.05) \text {. } \\
\text { NS: Non Significant } \\
\text { In the finding in present study showed (Table } 6) \text { that larger portion size was observed compare to } \\
\text { SSPS for bajra chapatti, maize chapatti bajra flour chapatti, wheat flour chapatti,missi } \\
\text { chapatti ,maize methi chapatti. Statistical analysis of data showed a highly significant difference } \\
(\mathbf{p}<0.01) \text { found for all chapatti. }\end{array}$} \\
\hline
\end{tabular}


Table.7 Mean \pm SD and t-values of portion size of cereals and millet based food products for in terms of weight

\begin{tabular}{|r|l|l|l|l|l|l|l|l|}
\hline $\begin{array}{l}\text { S. } \\
\text { No. }\end{array}$ & Name of Bhatura's & $\mathbf{N}$ & $\begin{array}{c}\text { SSPS } \\
\mathbf{( g )}\end{array}$ & Mean & Difference & SD & SE & t-value \\
\hline 1. & Plain Bhatura & 60 & 100 & 108.33 & 8.33 & 11.89 & 1.53 & $5.431^{* *}$ \\
\hline 2. & Plain Roasted Bhatura & 60 & 138 & 112.13 & -25.87 & 15.07 & 1.95 & $13.304 * *$ \\
\hline 3. & Bhatura (Plain, Fried) & 50 & 100 & 100.00 & 0 & 11.29 & 1.60 & $0.00^{\text {NS }}$ \\
\hline 4. & $\begin{array}{l}\text { Bhatura (Dal Stuffed) } \\
\text { 5. }\end{array}$ & 50 & 188 & 188.00 & 0 & 36.78 & 5.20 & $0.00^{\text {NS }}$ \\
\hline & $\begin{array}{l}\text { Bhatura (Calocasia } \\
\text { Stuffed) } \\
\text { ** Significant at 1\% (P<0.01) } \\
\text { * Significant at 5\% (P<0.05) }\end{array}$ & 10 & 181 & 171.95 & -9.05 & 19.08 & 6.03 & $1.50^{\text {NS }}$ \\
\hline
\end{tabular}

In the finding in present study showed (Table 6) that larger portion size was observed compare to SSPS for bajra chapatti, maize chapatti bajra flour chapatti, wheat flour chapatti, missi chapatti ,maize methi chapatti. Statistical analysis of data showed a highly significant difference $(\mathrm{p}<0.01)$ found for all chapatti.

Statistical analysis of data in Table 7 showed that a highly significant $(\mathrm{P}<0.01)$ difference were found between SSPS and mean of observed portion size for Plain bhatura and plain roasted bhatura whereas No significant difference was observed for bhatura (plain, fried), bhatura (dal stuffed), bathura (calocasia stuffed). Bread constituted a large portion of diet with over 43 percent subjects reporting consumption of bread.

Turconi et al., (2005) shows that weights of portion sizes chosen from the set of photographs are significantly associated $(\mathrm{P}<0.05)$ to weights of eaten portions (beta $=0.81 ; \quad R(2)=0.70)$. The differences between mean weights of the portions chosen by individuals from photographs and mean weights of eaten foods are significant for all food categories $(\mathrm{P}<0.05)$, except for bread. Bread constituted a large portion of the urban diet due to its convenience availability and low cost.

Portion sizes seem to have increased considerably over the last few decades. It is important to continue studying trends in actual portion size development. The present study demonstrated portion size of flat breads is larger in terms of weight compare to Suggest standard portion size because, major energy source of Indian diet are breads. Standardising declared serving sizes may improve the usability of nutrition information. Standardisation based on the dietary guidelines may assist consumers in following dietary recommendations and improve portion size selections.

\section{References}

Anderson A.S., Barton K., Craigie A., Freeman J., Gregor A., Stead M. NHS Scotland; Edinburgh: 2008. Exploration of adult food portion size tools

Capaldi E.D., Owens J.Q., Privitera G.J. Isocaloric meal and snack foods 
differentially affect eating behavior. Appetite. 2006; 46(2): 117-123.

Carels R.A., Konrad K., Harper J. Individual differences in food perceptions and calorie estimation. An examination of dieting status, weight, and gender. Appetite. 2007; 49(2): 450-458.

Carlsen, M., Lillegaard, I., Karlsen, A., Blomhoff, R., Drevon, C., Andersen, L., (2010). "Evaluation of energy and dietary intake estimates from a food frequency questionnaire using independent energy expenditure measurement and weighed food records. Nutrition Journal. 9: 37.

Das A., Raychaudhuri U, and Chakraborty R. (2012) Cereal based functional food of Indian subcontinent: a review. Journal of Food Science Technology 49(6): 665-672.

Japur C.C., Diez-Garcia R.W. Food energy content influences food portion size estimation by nutrition students. Journal of Human Nutrition and Dietetics. 2010; 23(3): 272-276.

Matthiessen J, Fagt S, Biltoft-Jensen A et al., (2003) Size makes a difference. Public Health Nutr., 6, 65-72.

Nelson, M. and Haraldsdottir, J. (1998a) 'Food photographs: practical guidelines II: Development and use of photographic atlases for assessing food portion size'. Public Health Nutrition, 1(4), 231-237.

Nelson, M. and Haraldsdottir, J. (1998b) 'Food photographs: practical guidelines I. Designs and analysis of studies to validate portion size estimates'. Public Health Nutrition, 1(4), 219-230.

Parimala, K R and Sudha M Lyan (2013), Wheat-Based Traditional Flat Breads of India, Critical Reviews in Food Science and Nutrition, 55(1).

Prentice A.M., Jebb S.A. Fast foods, energy density and obesity. A possible mechanistic link. Obesity Reviews. 2003; 4: 187-194.

Shimizu M., Payne C.R., Wansink B. When snacks become meals. How hunger and environmental cues bias food intake. International Journal of Behavioral Nutrition and Physical Activity. 2010; 7: 63.

Turconi, M., Guarcello, M., Berzolari, F.G., Carolei, A., Bazzano, R. and Roggi, C. (2005) 'An evaluation of a color food photography atlas as a tool for quantifying food portion size in epidemiological dietary surveys'. European Journal of Clinical Nutrition, 59(8), 923-931.

Verma T.,Raghuvanshi R S. (2002) Nutriguide. Manual for Calculation of Dietary Adequacy Using Nutrient Composition of Indian Recipes. All India coordinate research programme in Home Science.

Yang S, Gemming L, and Rangan A (2018). Large Variations in Declared Serving Sizes of Packaged Foods in Australia: A Need for Serving Size Standardisation? Nutrients, 10(2)

Yeomans M.R., Blundell J.E., Leshem M. Palatability. Response to nutritional need or need-free stimulation of appetite. British Journal of Nutrition. 2004; 92(Suppl. 1): S3-S14.

Zheng $\mathrm{M}$, Jason $\mathrm{H} \mathrm{Y}$, Wu Yu Louie J C. Victoria M F, Gill T, Thomas B, Cleanthous X, Neal B and Rangan (2016). A Typical food portion sizes consumed by Australian adults: results from the 201112 Australian National Nutrition and Physical Activity Survey. Scientific Reports. 6: 195-96

\section{How to cite this article:}

Mahajani, K., S. Jain and Dhaka, B.L. 2019. Portion Size Estimation of Indian Flats Breads in Terms of Weight. Int.J.Curr.Microbiol.App.Sci. 8(02): 815-822.

doi: https://doi.org/10.20546/ijcmas.2019.802.093 